\title{
The petrology of the Rex Mine kimberlite fissures, central Free State, South Africa
}

\author{
K. J. Machin ' and E. S. Barton ${ }^{2}$
}

1. Anglo American Research Laboratories (PTY) Ltd. P.O.Box 106, Crown Mines. 2025, South Africa

2. Hugh Allsopp Laboratory, Bernard Price Institute of Geophysical Research, University of the Witwatersrand. Wits 2050. Johannesburg, South A frica

This study describes the results of petrographic and various geochemical analyses conducted on seven kimberlite samples (samples 2 -8) from Rex Mine, obtained courtesy of Rex Mining Corporation.

Rex Mine is situated on the farm Stieniesrus, approximately 10 kilometers north of the town of Theunissen in the central Free State (Map 1). The kimberlite on the property occurs as a closely spaced system of dykes, and forms part of the western extension of the South Line of the Theunissen kimberlite cluster. The dykes have intruded flat lying shales and sandstones of the Late Permian to Early Triassic Beaufort Series of the Karoo Supergroup. Dolerite dykes and sills which predate the kimberlite are common in the area (Hill, 1989).

The kimberlite is classified petrographically as an olivine-rich. micaceous Group II kimberlite of the hypabyssal facies. Samples $2-7$ are derived from various dykes and are classified as uniform or uniform to segregationary textured macrocrystic phlogopite kimberlite, while sample 8 is derived from a blow on a dyke and is classified as a segregationary textured, lithic-rich kimberlite breccia. Diopside is relatively rare in the samples studied. which may suggest that the kimberlite is reasonably unevolved (Mitchell. 1995). Primary groundmass minerals include fine-grained phlogopite. spinel. apatite. perovskite and calcite. The whole rock $\mathrm{TiO}_{2} / \mathrm{Y}$ and $\mathrm{Zr} / \mathrm{Nb}$ concentration ratios confirm the petrographic classification of the samples as Group II kimberlites.

The indicator mineral chemistry of samples 4.7 and 8 is compared. not only with each other, but also with data for the eleven neighbouring kimberlite localities studied by Hill (1989). These include three dykes at Star Mine. the Retreat. Hendriena. Leliesdal and Braklaagte dykes. as well as Monteleo Mine. Rex Mine. Geomine and Driekoppies pipe.

According to the Gurney (1984) classification system. the total garnet population of the three samples consists predominantly of G09 and G10 garnets, as well as a significant proportion of eclogitic and low- $\mathrm{Cr}_{2} \mathrm{O}_{3}$, high- $\mathrm{TiO}_{2}$ megacrystic grains (Fig.1). A high proportion of the grains analysed from each sample fall within the G10 compositional field. being most abundant in sample 4. The lherzolitic (G09) garnet population of each sample includes a number of high- $\mathrm{Cr}_{2} \mathrm{O}_{3}$ grains. Despite a smaller dataset, the total garnet population from the kimberlites studied by Hill (1989) is very similar to that of this study.

A comparison is made between samples 4.7 and 8 and the eleven localities of Hill's thesis (1989) in terms of the percentage of peridotitic garnets present. This demonstrates that certain dykes in the Theunissen cluster show a wide variation in the proportion of peridotitic or eclogitic garnets along strike.

The garnet mineral chemistry of the samples suggests that the kimberlite dykes at Rex Mine have sampled a mantle composed of garnet harzburgite, garnet lherzolite and minor eclogite.

The spinels from the three Rex Mine samples are chemically similar and exhibit typical kimberlitic trends on the $\mathrm{Cr}_{2} \mathrm{O}_{3}$ vs $\mathrm{MgO}$ plots of Gurney (1989). The spinel population from each sample is 
characterised by high average $\mathrm{Cr}_{2} \mathrm{O}_{3}$ contents and a significant proportion of grains that plot within the field of compositions associated with diamond inclusions (Fig. 2). A similar scenario exists for the total spinel population from Hill's thesis (1989). despite the use of a considerably smaller dataset. The chemical consistency demonstrated by the spinels from Rex Mine and surrounding localities suggests that the various kimberlite dykes in the cluster sampled a mantle of similar composition in a broadly similar manner.

Ilmenite is rare in the Rex Mine samples (Fig.3), and is absent from the concentrate samples of the eleven neighbouring localities. According to the classification system of Sobolev et. al (1992), virtually the entire clinopyroxene population extracted from the three Rex Mine samples is derived from garnet peridotite (Fig. 4).

The trace element geochemistry of a preferentially selected garnet population was determined by LA-ICP-MS analysis. The resultant pressure-temperature data suggest a geotherm of $37 \mathrm{~mW} / \mathrm{m}^{2}$ and indicate that a moderate to high degree of sampling occurred within the diamond stability field. Sampling by the kimberlite of a depleted lithosphere, with little evidence for melt or hydrous metasomatism. is also indicated.

Five mica samples from sample 6 and five from sample 7 were selected for ${ }^{87} \mathrm{Rb} /{ }^{86} \mathrm{Sr}$ age analysis. Regressing 9 of the samples (excluding one from sample 7) yields an errorchron age result of $135 \pm$ $6 \mathrm{Ma}$. with an initial Sr ratio of $0.711 \pm 0.002$. This age is in accordance with known ages of other Group II kimberlites, for example Lace Mine in the Kroonstad area (Phillips et. al., 1998).

The petrographic analysis, indicator mineral chemistry and garnet geochemistry indicate that the Rex Mine kimberlite is highly favourable in terms of its diamond-bearing potential. This is consistent with the known diamond production of the mine (A. Jackson. pers. comm.).

\section{References:}

Phillips, D.. Kiviets. G.B.. Barton. E.S., Smith. C.B., Viljoen. K.S. and Fourie, L.F. $1986 .{ }^{40} \mathrm{Ar} /{ }^{39} \mathrm{Ar}$ dating of kimberlites and related rocks: problems and solutions. Abstract $7^{\text {th }}$ Int. Kimb. Conf.. Cape Town.

Gurney. J. J.. 1984. A correlation between garnets and diamonds. In: Glover J. E. \& Harris P. G. (Eds). Kimberlite Occurrence and Origin: a basis for conceptual models in exploration, pp. 143 - 166. Geology Dept. and Univ. Extension, Univ. of Western Australia, Publ. No. 8.

Gurney. J. J.. 1989. Diamonds. In: J. Ross (Ed.), Kimberlites and related rocks, Vol. 2. Proc. $4^{\text {th }}$ Int. Kimb. Conf.. Perth. 1986. Geol. Soc. Australia Spec. Publ. No. 14. pp. 935-965.

Hill. S.J.. 1989. A study of the diamonds and xenoliths from the Star kimberlite, OFS, South Africa. M.Sc. thesis: University of Cape Town (Unpupl.).

Mitchell, R. H., (1995). Kimberlites, Orangeites and Related Rocks. Plenum Press, New York.

Ryan. C.G. et al., 1996, Garnet geotherms: pressure-temperature data from Cr-pyrope garnet xenocrysts in volcanic rocks. In: J. of Geophysical Research. Vol. 101, No. B3. pp. $5611-5625$.

Sobolev, N.V., Pokhilenko, N.P., Grib, V.P., Skripnichenko, V.A. and Titova, V.E., 1992. Specific composition and conditions of formation of deep-seated minerals in explosion pipes of the Onega peninsula and kimberlites of Zimnii coast in the Archangelsk province. Soviet Geol. and Geophysics, Vol. 33, No. 10, pp 71-78. 


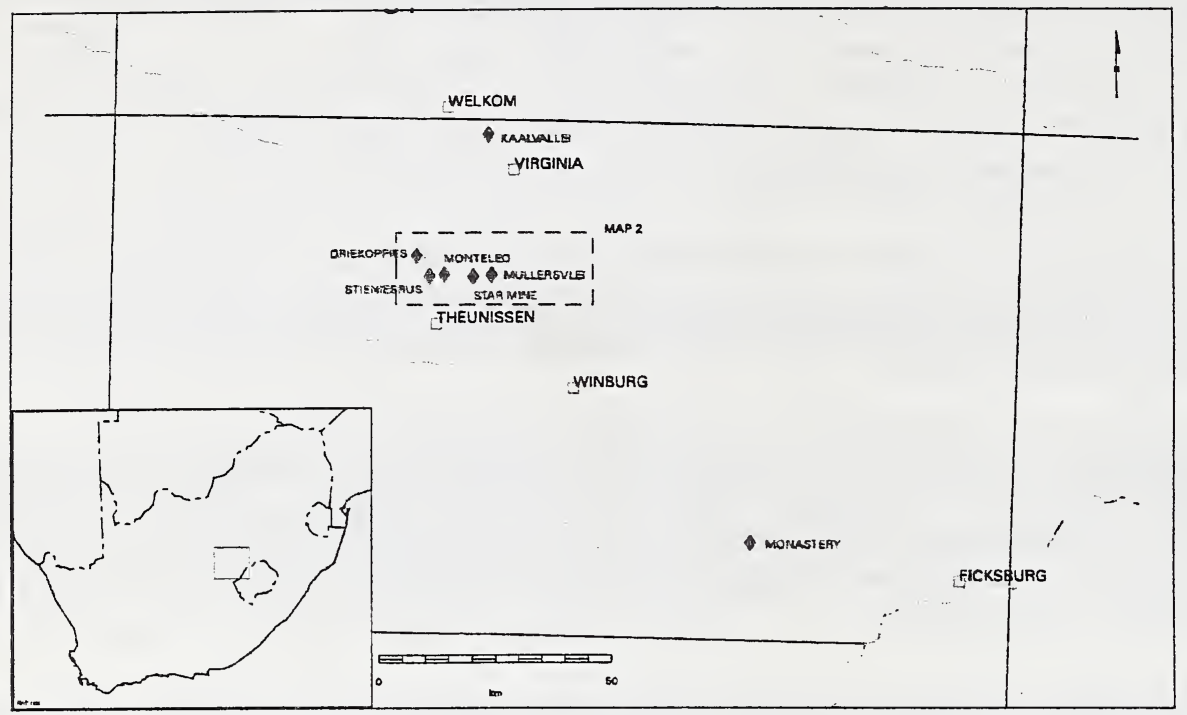

Map 1: Locality map of selected kimberlites showing the position of Rex Mine (Stieniesrus) within the Theunissen kimberlite cluster. The inset shows the location of the main map area.
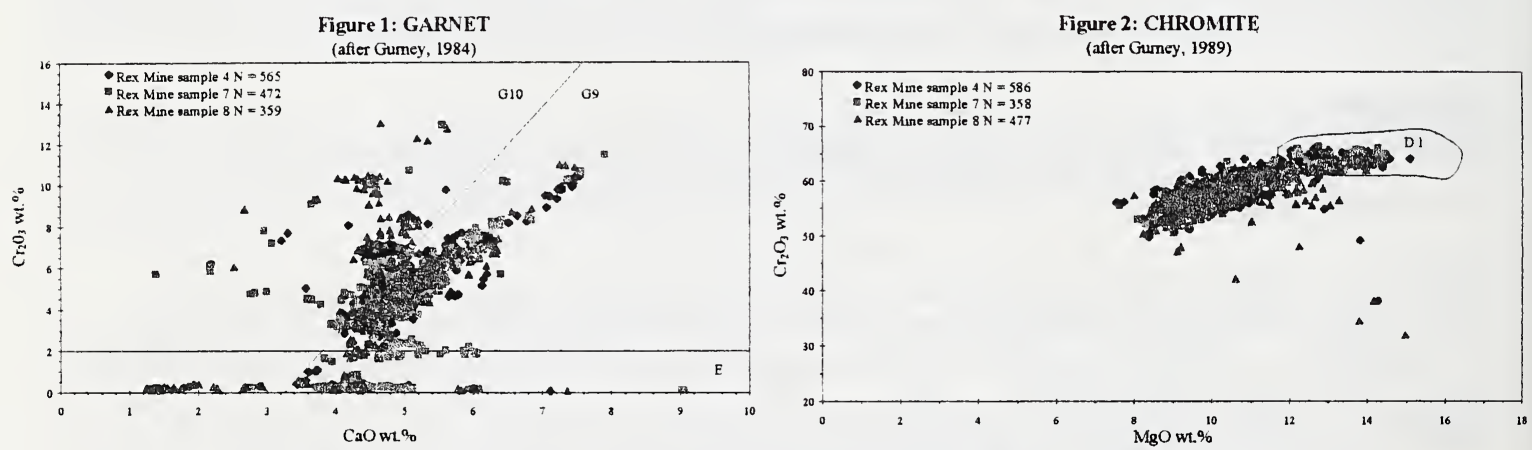

Figure 3: lLMENITE
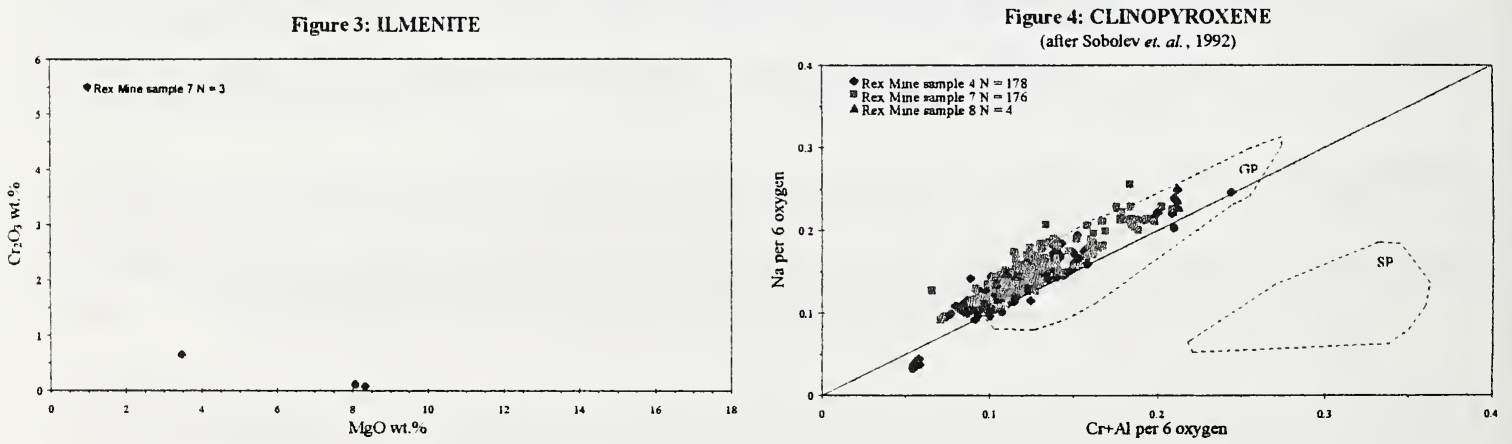

Figures 1 - 4: Indicator mineral chemistry plots for samples 4, 7 and 8. IImenite occurs exclusively in sample 7. 